\title{
OBITUARIES
}

\section{PROFESSOR VLADIMIR MINORSKY}

Professor Vladimir Minorsky, who died at the age of 89 on 25th March, 1966, was a scholar of quite outstanding distinction, whose impact on Oriental studies will be felt for many generations. Looking back upon the wide range of his vast output he himself wrote in the Foreword to his volume Iranica (1963), which includes a full list of his publications under 209 headings covering nearly twice that number of items: "Iranian subjects stand definitely in the forefront of my interests. But Iran, its history and its literature, have ever been linked with the life of many peoples near and far, and I have often been tempted to trace these contacts and interactions." By yielding to such temptations he was led to study in depth, and illuminate, a large variety of problems of Caucasian, Armenian, Mongol, Turkish, Russian, and Byzantine history, in addition to his main work on Persian.

In the field of the historical geography of Persia, the Caucasus, and Central Asia he was the supreme authority of our time, a true successor of Barthold and Markwart, the two scholars in whose work he found constant inspiration while continuously extending its scope. His interest in historical topography had received an unusual practical outlet before he turned entirely to scholarship, when as Imperial Russian Commissioner on the Mixed Commission for the Delimitation of the Turco-Persian Frontier he surveyed on horseback the whole 700 miles of that frontier, from the Persian Gulf to Mount Ararat, in 191314. Even earlier he had travelled extensively in north-west Persia and Central Asia while in the service of the Russian Ministry of Foreign Affairs. His grasp of the lie of the lands he had seen came to stand him in good stead whenever he treated texts referring to them, as in the case of his important identification of the name of the fort of Paswe with the ancient Parsua, towards which Sargon II states that he had "descended" (BSOAS, XIX, 1957, 79; cf. J. V. Kinnier Wilson, Iraq, XXIV, 1962, 111).

Professor Minorsky acquired his unrivalled familiarity with Islamic historical and geographical sources while collecting material over many years, first in Paris and later in London, for the 110 articles he wrote between 1925 and 1937 for the first edition of the Encyclopaedia of Islam. To the copy-books he filled at the time, he kept adding notes from his continuous reading ever after, drawing on them as need arose. Simultaneously with the $E I$ articles he worked on his opus magnum, which was published in 1937: the translation of, and commentary to, the Hudüd al-Alam ("Regions of the World"), a 10th-century Persian geography whose anonymous author he tentatively identified 25 years later (1962) with Ibn Farighūn.

The $E I$ articles, to which he added 21 new ones for the second edition, have become indispensable tools for all who work on the subjects he treated. The Hudüd is a masterpiece of erudition and ingenuity. It was in this book that he displayed for the first time on a massive scale his unique skill in emending corrupt place names. There was a touch of magic in the emergence of a suitable toponym from an incomprehensible sequence of letters after his deletion, addition, or shifting of a dot or two, the coaxing of a $د$ into, position, the eversion of a $\dot{\dot{ }}$ to $\dot{\sim}$, or the straightening of a $S$ to $\mathrm{J}$. Dangerous in lesser hands, such procedure, based on immense experience of the vagaries of manuscript spellings, 
and controlled by strict inquiry into the suitability of proposed emendations, was employed with felicitous results by him because he knew where to stop. Few of his countless emendations have been successfully challenged.

When the Hudüd appeared in his sixtieth year it was hailed as the crowning achievement of a rich scholarly life. Yet its author had by then barely reached the half-mark of his stupendous output. Seven pioneering books were still to follow; 67 articles exploring in depth a wide variety of difficult problems; the 21 additional $E I$ articles, and three in the Encyclopaedia Britannica; 33 reviews, many of them offering new contributions; and translations, in collaboration with Mrs. Minorsky, of four Russian books on Oriental subjects.

The horizon opened by the Hudüd was extended and further explored by him in two books consisting of first editions with translation and commentary of 10th- and 11thcentury Arabic texts rich in novelties. One is Marvazi on China, the Turks, and India (1942), where the Arabic text was reproduced from his own beautiful handwriting; the other, published in Cairo (1955), Abu Dulaf Mis'ar Ibn Muhalhil's Travels in Iran (circa A.D. 950). Stressing the need to extend to Islamic writings the critical methods of classical studies for the elucidation of sources underlying the texts in hand, he consistently employed them in both books, as he had done in the Hudüd. Problems of historical geography continued to engage him to the end of his life. His last article, a true gem written shortly before his death, solves a particularly interesting one. It is due to appear in BSOAS under the title "A Greek crossing of the Oxus".

In the domain of history Professor Minorsky struck out new paths no less forcefully than in geography. Although he did on one occasion record in concise form his considered views on the development of Islamic Persian history from the beginnings to the present day (Civiltà Orientali, Rome, 1956, 461-513), he held no brief for general "outlines", knowing that the spade-work which would assure their reliability was still far from having been completed. Instead he applied himself tenaciously to the unravelling of difficult sources for the purpose of establishing the precise conditions obtaining at given times in given areas. The two books which constitute the masterpiece of his advanced maturity (Studies in Caucasian history, 1953, and A history of Sharvãn and Darband in the 10th-11th centuries, 1958, conceived as two volumes of a single work) bring to life the forgotten past of a vast Transcaucasian area from Armenia to the Caspian, from sources which had remained untapped or were but imperfectly understood. An important discovery peculiarly his own is the existence in the 10th century of a western "Iranian intermezzo" that formed a pendant to the eastern "Persian renaissance" of Khorasan. This interlude between the periods of Arab and Turkish domination over central and western Persia, as well as over Armenia, had as protagonists a number of local Iranian dynasties, partly Daylamite and partly Kurdish, whose vicissitudes and significance for the continuity of Iranian tradition have only become clear thanks to Professor Minorsky's patient research.

Another period of western Iranian history which he did much to illuminate is the "Turkman century", the 15 th, in which he recognized the starting-point of many important developments in Persia and Turkey. After devoting eleven articles of "Turkmenica" to this period, he concluded the series at the age of 80 with a vivid Royal Asiatic Society Monograph, Persia in A.D. 1478-1490. Many other historical episodes and situations inside and outside Persia were investigated by him. He also has the great merit of having 
inspired Dr. Boyle to accomplish this century's most important translation of a Persian historical work, Juvayni's History of the World Conqueror, as Dr. Boyle testified in his warm-hearted acknowledgement on p. xii of the first of its two volumes.

In the field of Persian literature Professor Minorsky will be remembered first and foremost for promoting in four weighty articles the recognition, which promptly acted as a stimulant to further discoveries (see Mary Boyce, $J R A S, 1957,10-45$ ), that Gurgani's romance Vis $u$ Ramin, a tale that has affinities with Tristan and Isolde, springs from a Parthian background. He also published a study of the Old Preface of the Säh Nãmeh, and wrote a searching article on one of the greatest, yet on account of the difficulty of his verses least known, Persian poets, Afụal al-Din Ibrāhim Khāqāni. To the 13th-century poet Pūr-i Bahā, whom he rescued from undeserved neglect, he devoted two articles, one of which owes its revealing force to the author's familiarity with Mongol terminology and habits, to which also his historical work bears ample witness. Other Persian writers studied by him include Bābā Țāhir, Omar Khayyām, and Qāḍi Ahmad, of whose treatise on Calligraphers and Painters (written c. 1606) he published a most engaging translation in 1959.

On Iranian dialectology Professor Minorsky left his mark through valuable observations on the Tât dialects, the peculiarities of the lost Daylamite language, and Gurani. He knew Kurdish, and launched the interesting theory that the Kurds descend from the Medes.

As Oriental Secretary to the Persian Art Exhibition of 1930-31 in London he took a large share in the compilation of its catalogue. Thereafter he gave a paper in which for the first time the Luristan bronzes were connected with the Cosseans (1931), and wrote an article on "The Geographical Factors in Persian Art" (1938). The magnificent volume of his Catalogue of the Turkish manuscripts and miniatures of the Chester Beatty Library (1958) also falls under the heading of art.

Even with religion he concerned himself. His early book on the Persian sect of the Ahl-i Haqq (1911) earned him the gold medal of the Section of Ethnography of the Imperial Society of Natural Sciences of Moscow. He returned to this sect with a second book published in Paris (1920), and with articles written in 1921, 1928, 1934, and 1956.

The above account, cursory as it is, of Professor Minorsky's output, will give some idea of the versatility, productivity, and originality of this great scholar. $\mathrm{He}$ was also a most stimulating teacher, always ready to place his time and immense knowledge at the disposal of gifted students. His teaching activity began in Paris where, after giving up his diplomatic career, he became Lecturer in Persian literature at the École Nationale des Langues Orientales Vivantes in 1923. In 1932 he was appointed Lecturer in Persian at the London School of Oriental Studies. After one year his Lectureship was converted into a Readership, and in 1937 he succeeded Sir Denison Ross in the Chair of Persian. In 1944 he became Professor Emeritus. With the School of Oriental Studies, when it was evacuated in 1939, he moved to Cambridge, where he made his home for the rest of his life, with the exception of the four months which he spent as Visiting Professor at the Fu'ad University in Cairo (1948-49).

The small town of Korcheva, north-west of Moscow on the Upper Volga, where Professor Minorsky was born on 5th February, 1877, no longer exists. It was submerged at the bottom of the Moscow Sea when the river was dammed as part of a plan for the 
expansion of inland navigation. He was educated in Moscow, where he entered the University in 1896 as a gold medallist of the Fourth Grammar School. After graduating in Law (1900) he studied Oriental languages at the Lazarev Institute from 1900 to 1903. His teachers included A. E. Krymski for Arabic, F. E. Korsh and Baron R. von Stackelberg for Persian, and Vsevolod F. Miller for history; to these he would proudly add from his much later time in Paris the great Persian scholar M. Qazvini, with whom he discussed every Thursday the difficult points he had met during the week. Having entered in 1903 the Russian Ministry of Foreign Affairs, he served from 1904 to 1908 in Persia, from 1908 to 1912 in St. Petersburg and Central Asia. In 1912 he was appointed to the Russian Embassy in Constantinople. After representing his country on the Turco-Persian Frontier Commission, he became First Secretary and later Chargé d'affaires at the Russian Legation in Teheran. In 1919 he was attached to the Russian Embassy in Paris where, having by then seventeen learned publications to his credit, he decided to devote himself exclusively to scholarship.

He had married in 1913 Tatiana Shebunina, who survives him. They had the great grief of losing their only son in 1950. Mrs. Minorsky was with her husband throughout his inspection of the Turco-Persian frontier. Later she typed all his manuscripts, compiled the indexes to his books, and collaborated with him in the translation from the Russian of Orientalist works, in addition to acting as delightful hostess to his numerous visitors. In the last eight years of his life, when his reading had to be confined largely to writings in Arabic script, she did most of the proof-reading, and enabled him to keep abreast with progress in his field by reading to him extensively in four European languages.

Of the three gold medals he received, the last was awarded to him by the Royal Asiatic Society in 1962. Honorary doctorates were conferred on him by the Universities of Brussels and Cambridge. He was a Corresponding Fellow of the British Academy, a Membre de l'Institut de France (Académie des Inscriptions et Belles Lettres), an Honorary Fellow of the School of Oriental and African Studies, and an honorary member both of the Société Asiatique and the Deutsche Morgenländische Gesellschaft. A special issue of $B S O A S$, consisting of articles presented by colleagues and friends, was published in his honour in 1952 , on the occasion of his seventy-fifth birthday and the twentieth anniversary of his joining the University of London.

In 1960 he was invited by the Soviet Academy of Sciences to attend the twenty-fifth International Congress of Orientalists in Moscow. It was his first visit to his country after the Revolution. The reception accorded to him in Soviet academic circles was nothing if not triumphant, and for good reasons. Apart from being the most eminent Russian Iranologist, he had done more than anybody else to spread in the West the knowledge of Soviet scholarly publications in his own and related fields, while conversely making Western publications available to Soviet scholars. A truly international figure, he nevertheless maintained a deep concern for the due appreciation abroad of Soviet scholarship, on whose quality and progress he exerted a powerful influence even from a distance, through correspondence.

His personality radiated warmth and friendliness. Although constantly productive, and engaged in pioneer work to the end, he always found time to extend a cordial welcome to visitors, of whom his distinction in the subjects of his choice attracted a steady flow 
from many parts of the world. He would entertain them for hours, taking a lively interest in their activities, giving cautious advice if asked (and not otherwise), posing and discussing literary or historical problems ancient and current, illustrating his points with apt quotations that would occur to him from nine literatures, reminiscing about famous men he had known, places he had seen, events he had taken part in. His memory, spanning eighty years of reading and experience, was awe-inspiring. From it he would occasionally produce tunes he had heard scores of years earlier, music, including piano-playing, having been one of his relaxations. As one sat in his study, listening to this man on the threshold of his nineties, one could only marvel at his zest for life, the youthful eagerness with which he inquired about new books and articles (although mostly it was he who would put his visitors up to date), his informedness on current affairs, and the shrewdness, sharpened by early diplomatic training, with which he appraised them. With all his achievements and fame, there was no conceit in him. He was always ready to learn from anybody, and would go to great lengths to consider any criticism levelled at him, accepting it gracefully if it proved just.

His physical appearance, which until the end suffered little change from his youthful sixties, is best conveyed by a photograph reproduced in his volume Iranica mentioned at the beginning. To keep pace with this stocky, straight, and brisk octogenarian, as he determinedly wound his way through London's rush-hour traffic towards some meeting, was an experience both harassing and exhilarating.

Professor Minorsky's rich, long life conformed even at the last stage to a rule whose validity is all too often impaired long before death: that a creative and hard-working scholar's perceptive ability and speed of discovery progress in geometric proportion to the number of years he is given to accumulate knowledge and experience. "Game runs towards the expert hunter" was his favourite Russian proverb in old age. More game than ever was converging on him when his hour arrived. This is why the loss suffered by Oriental studies, not to speak of those who knew and loved him, is beyond measure. There is comfort only in the thought that what makes the loss so obvious is the immense gain which preceded it. It is a gain which will long continue to quicken human endeavour.

\section{ILYA Gershevitch.}

\section{DENYS HENRY BRAMALL}

Mr. D. H. Bramall, the Honorary Solicitor to the Royal Asiatic Society, died on 26th May, 1966, at the age of 67. He saw service in the Royal Artillery in both World Wars, attaining the rank of Major and being awarded the M.B.E. as well as the Territorial Decoration. He joined the firm of T. L. Wilson and Company as a partner in 1934, and had been Honorary Solicitor to the Society since 1947. In this capacity his breadth of experience and timely counsel will be sorely missed by those concerned with ordering the Society's affairs.

H. L. S. 